\title{
EFFECTS OF AS-CAST AND WROUGHT COBALT-CHROME-MOLYBDENUM AND TITANIUM-ALUMINIUM-VANADIUM ALLOYS ON CYTOKINE GENE EXPRESSION AND PROTEIN SECRETION IN J774A.1 MACROPHAGES
}

\author{
Stig S. Jakobsen ${ }^{1,2 *}$, A. Larsen², M. Stoltenberg², J.M. Bruun ${ }^{3}$, K. Soballe ${ }^{1}$ \\ ${ }^{1}$ Department of Orthopaedics, Aarhus University Hospital, Aarhus, Denmark \\ ${ }^{2}$ Department of Neurobiology, Institute of Anatomy, University of Aarhus, Denmark \\ ${ }^{3}$ Department of Endocrinology and Metabolism C, Aarhus University Hospital, Denmark
}

\begin{abstract}
Insertion of metal implants is associated with a possible change in the delicate balance between pro- and antiinflammatory proteins, probably leading to an unfavourable predominantly pro-inflammatory milieu. The most likely cause is an inappropriate activation of macrophages in close relation to the metal implant and wear-products. The aim of the present study was to compare surfaces of as-cast and wrought Cobalt-Chrome-Molybdenum (CoCrMo) alloys and Titanium-Aluminium-Vanadium (TiAlV) alloy when incubated with mouse macrophage J774A.1 cell cultures. Changes in pro- and anti-inflammatory cytokines [TNF- $\alpha$, IL-6, IL-1 $\alpha$, IL-1 $\beta$, IL-10] and proteins known to induce proliferation [M-CSF], chemotaxis [MCP-1] and osteogenesis [TGF- $\beta$, OPG] were determined by ELISA and Real Time reverse transcriptase - PCR (Real Time rtPCR). Lactate dehydrogenase (LDH) was measured in the medium to asses the cell viability. Surface properties of the discs were characterised with a profilometer and with energy dispersive X-ray spectroscopy. We here report, for the first time, that the prosthetic material surface (nonphagocytable) of as-cast high carbon CoCrMo reduces the pro-inflammatory cytokine IL-6 transcription, the chemokine MCP-1 secretion, and M-CSF secretion by 77 $\%, 36 \%$, and $62 \%$, respectively. Furthermore, we found that reducing surface roughness did not affect this reduction. The results suggest that as-cast CoCrMo alloy is more inert than wrought CoCrMo and wrought TiAlV alloys and could prove to be a superior implant material generating less inflammation which might result in less osteolysis.
\end{abstract}

Key Words: CoCrMo, titanium, inflammation, cytokine, real time RT-PCR, surface, osteolysis, J774A.1 macrophage, dissolucytosis.

\footnotetext{
*Address for correspondence:

Stig S. Jakobsen

Department of Orthopaedics

Aarhus University Hospital

Tage-Hansens Gade 2

DK-8000 Aarhus, Denmark
}

E-mail: Stig.Jakobsen@ki.au.dk

\section{List of abbreviations}

$\begin{array}{ll}\text { IL-1 } \alpha & \text { Interleukin-1 alpha } \\ \text { IL-1 } \beta & \text { Interleukin-1 beta } \\ \text { IL-6 } & \text { Interleukin-6 } \\ \text { IL-10 } & \text { Interleukin-10 } \\ \text { MCP-1 } & \text { Monocyte chemotactic protein-1 } \\ \text { M-CSF } & \text { Macrophage Colony-Stimulation Factor } \\ \text { OPG } & \text { Osteoprotegerin } \\ \text { TGF- } \beta & \text { Transforming growth factor beta } \\ \text { TNF- } \alpha & \text { Tumor necrosis factor-alpha }\end{array}$

\section{Introduction}

Advanced manufacturing techniques have made it possible to create promising Cobalt-ChromeMolybdenum (CoCrMo) metal on metal hip prostheses with excellent wear-properties and biocompatibility. The alloy is available with high $(>0.2 \mathrm{wt} \%)$ or low $(0.07 \mathrm{wt}$ $\%)$ carbon content and manufactured either wrought or cast (Nevelos et al., 2004). Low carbon (LC) alloy is softer than high carbon (HC) alloy and less durable (Firkins et al., 2001). Using the cast manufacturing method makes it possible to produce complex prosthetic designs with very low tolerances.

Macrophages are important immunological players in aseptic loosening of orthopaedic implants (Ingham and Fisher, 2005; Thomsen and Gretzer, 2001) and Horowitz demonstrated that media from cells incubated with CoCrMo wear-particles could induce bone resorption in a mouse scull (Horowitz et al., 1998). Macrophages react to wear-particles in a standardized way, expressing and/ or releasing pro-inflammatory cytokines, cytokines known to induce proliferation of macrophages and induce chemotaxis [chemokines] (Garrigues et al., 2005). These cytokines and numerous other pro-inflammatory molecules are found in the proximity of loose implants (Goodman, 2005; Wooley and Schwarz, 2004) leading to attraction of monocytes and transformation of immature macrophages to osteoclasts with a prolonged survival, resulting in an increased bone resorption.

Immediately after an orthopaedic prosthetic device has been implanted the surrounding tissue forms a 10-100 $\mathrm{nm}$ thick biolayer on its surface (Roach et al., 2007) and macrophages contact the biolayer (Futami et al., 2000; Sennerby et al., 1993). The contact is mediated by an activation of the complement system where $\mathrm{C} 3$ adsorbs to the implant surface as $\mathrm{C} 3 \mathrm{~b}$ where upon it complexes with complement factor $\mathrm{B}$ or factor $\mathrm{H}$ resulting in 
formation of C3b or iC3B respectively (Kao et al., 1999; Walivaara et al., 1994). C3b and iC3B are both ligands for macrophage surface receptors. Fibronectin and vitronectin also adsorb to the implant surface and act as a ligand for macrophages through RGD-integrin receptor domains. These ligand-interactions and several others are the primarily interaction between implant surface and macrophages (Ziats et al., 1988) resulting in cytokine release independently of internalization of wear particles (Bi et al., 2002; Fritz et al., 2006; Nakashima et al., 1999). The release of metal ions take place as a result of the dissolucytes (macrophages) controlling the chemical milieu in the membrane (Danscher, 2002; Larsen et al., 2007 ) in a process called dissolucytosis. $\mathrm{Co}^{2+}$ and $\mathrm{Cr}^{3+}$ ions induce necrosis and apoptosis as well as secretion of TNF$\alpha$, IL-6, and PGE2 in various cell-types (Catelas et al., 2003; Lee et al., 1997). Few studies have investigated the surface (non-phagocytable foreign body) of implants where macrophages throughout the years interact with both corrosive products and surface properties. The aim of the present study was to investigate the pro-inflammatory, chemokine, and proliferate macrophage response by measuring the protein secretion and mRNA expression of key cytokines (TNF- $\alpha$, IL-6, IL- $1 \alpha$, IL-1 $\beta$, MCP-1, MCSF, IL-10, OPG and TGF- $\beta$ ) in J774A.1 cells after exposure to as-cast and wrought CoCrMo alloys compared to wrought Titanium-Aluminium-Vanadium alloy (TiAlV).

\section{Materials and Methods}

\section{Cell culture}

J774A.1 mouse macrophages (ATCC, Rockville, MD, USA) were exposed to either as-cast $\mathrm{HC} \mathrm{CoCrMo}$, wrought $\mathrm{HC}$ CoCrMo, wrought LC CoCrMo, or wrought TiAlV. Cells were maintained under standard culture conditions as described (Zdolsek et al., 1990). Briefly, cells were grown in a RPMI 1640 medium (GIBCO ${ }^{\circledR}$ supplied by Invitrogen, Abingdon, Oxon., UK) supplemented with 10\% foetal bovine serum (Biochrom, VWR Int., Rødovre, Denmark), $2 \mathrm{mM}$ glutamine, $100 \mu \mathrm{m} / \mathrm{ml}$ penicillin, 100 $\mu \mathrm{m} / \mathrm{ml}$ streptomycin, and $1 \%$ non-essential amino acids. The cells were maintained in plastic flasks (Nunc, Roskilde, Denmark) and subcultivated at confluence, usually 2-3 times a week and experiments were conducted after 4-8 passages. The adherent cells were harvested in freshly prepared cell medium using a plastic cell scraper (Nunc) and $5 \mathrm{ml}$ medium containing $5.0 \times 10^{6}$ cells were placed on the discs in Nucleon ${ }^{\mathrm{TM}} \mathrm{D}$ Surface 6 wells dishes (Nunc). Negative controls were done without the discs. After 8 hours supernatant were separated from the cells and frozen at $-20^{\circ} \mathrm{C}$. Cells were harvested with the plastic cell scraper, centrifuged, and quenched in liquid nitrogen and stored at $-80^{\circ} \mathrm{C}$ until further analyses. Discs were studied with $\mathrm{n}=5$.

\section{Assessment of the cytokine transcription and secretion}

\section{Protein levels of cytokines}

Supernatant from the cultures was thawed and analysed for the cytokines using a commercially available ELISA kit (R\&D Systems, Abingdon, Oxon., UK: Mouse TNF- $\alpha$ duoset Cat. No. DY410; Mouse IL-6 duoset, Cat. No. DY406; Mouse IL-1 $\alpha$, quantikine, Cat. No. MLA00; Mouse IL-1 $\beta$, quantikine, MLB00B; Mouse IL-10 duoset, No. DY417; Mouse M-CSF, quantikine, No. MMC00; Mouse MCP-1, duoset, No. DY479; Mouse TGF- $\beta$, quantikine, No. MB100B; Mouse OPG, quantikine, No. MOP00). Briefly, a $100 \mu \mathrm{L}$ sample was incubated in a well, coated with monoclonal antibody against the wanted cytokines for 2 hours at room temperature. Then the well was washed. The detection antibody was added and followed by 2 hours incubation at room temperature. After being washed again Streptavidin-Horseradish peroxidase was added, incubated for 20 minutes at room temperature, and finally stopped with $2 \mathrm{~N}$ nitric acid. The sample was then ready to be read at $450 \mathrm{~nm}$ in a SPECTRA II Reader (SLT Labinstruments, Salzburg, Austria).

\section{mRNA levels of cytokines. mRNA extraction}

TRIZOL $^{\circledR}$ Reagent (InvitrogenTM, life technologies, Taastrup, Denmark) was used to extract the mRNA. Three steps follow first homogenisation, second phase separation, and third RNA precipitation. In the homogenisation process cells were thawed and lysed in an RNase free $1 \mathrm{ml}$ polyethylene tube, by adding the reagent directly to the cells in the tube followed by repetitively pipetting. Centrifugation at $12,000 \mathrm{~g}$ for 10 minutes at $5^{\circ} \mathrm{C}$ leaves the RNA in the supernatant. The supernatant was moved to a new $1 \mathrm{ml}$ polyethylene tube. In phase separation chloroform was added to the samples and this separates the RNA into the aqueous phase. The aqueous phase was transferred to a fresh tube, where mixing with isopropyl alcohol precipitates RNA. On the bottom of the tube, a pellet was visible after centrifugation. After washing the RNA pellet, it was air dried briefly.

Measuring the optical density at $260 \mathrm{~nm}$ and $280 \mathrm{~nm}$ checks quantification of RNA and the ratio should be 1.8 or higher (Gene Quant II, Pharma Biotech, Buckinghamshire, UK). Electrophoresis was done with RNA on a $0.7 \%$ agarose gel. Staining the gel with ethidium bromide makes it possible to see discrete bands which should be between $7 \mathrm{kB}$ and $15 \mathrm{kB}$ in a good quality RNA separation. Finally, RNA was ready to reverse transcription and later real-time PCR.

\section{Reverse transcription}

The reverse transcription was made with random hexamer primers at $23^{\circ} \mathrm{C}$ for 10 minutes, $42^{\circ} \mathrm{C}$ for 60 minutes and terminated by increasing the temperature to $95^{\circ} \mathrm{C}$ for 10 minutes as described by the manufacturer (GeneAmp ${ }^{\circledR}$ PCR Kit, Perkin Elmer Cetus, Waltham, MA, USA). The primers used are listed in Table 1.

\section{Real-time PCR}

PCR-mastermix contains the specific primers, Hot Start Taq DNA polymerase, and SYBR-green together with 10 ng cDNA. 


\begin{tabular}{|c|c|c|}
\hline IL-1a & $\begin{array}{l}\text { forward, 5'- TTACAGTGAAAACGAAGA -3' } \\
\text { reverse, 5'- TGTTTGTCCACATCCTG -3' }\end{array}$ & $418 \mathrm{bp}$ \\
\hline IL-1及 & $\begin{array}{l}\text { forward, 5'- CTTCATCTTTGAAGAAGAGCCC -3' } \\
\text { reverse, 5'- CTCTGCAGACTCAAACTCCAC -3' }\end{array}$ & $418 \mathrm{bp}$ \\
\hline IL-6 & $\begin{array}{l}\text { forward, 5' TTCACAAGTCCGGACAGGAG 3' } \\
\text { reverse, 5' TGGTCTTGGTCCTTAGCCAC 3' }\end{array}$ & $488 \mathrm{bp}$ \\
\hline IL-10 & $\begin{array}{l}\text { forward, 5' - GGTTGCCAAGCCTTATCGGA -3' } \\
\text { reverse, 5'- ACCTGCTCCACTGCCTTGCT -3' }\end{array}$ & $191 \mathrm{bp}$ \\
\hline TGF- $\beta$ & $\begin{array}{l}\text { forward, 5'- TGGACCGCAACAACGCCATCTATGAGAAAACC-3' } \\
\text { reverse, 5'- TGGAGCTGAAGCAATAGTTGGTATCCAGGGCT-3' }\end{array}$ & $525 \mathrm{bp}$ \\
\hline TNF- $\alpha$ & $\begin{array}{l}\text { forward, 5'-CATCTTCTCAAAATTCGAGTGACAA-3' } \\
\text { reverse, 5'-TGGGAGTAGACAAGGTACAACCC-3' }\end{array}$ & $175 \mathrm{bp}$ \\
\hline M-CSF & $\begin{array}{l}\text { forward, 5'- TCTCATCAGTTCTATGGCCC -3' } \\
\text { reverse, 5'- GGGAGTAGACAAGGTACAAC -3' }\end{array}$ & $212 \mathrm{bp}$ \\
\hline MCP-1 & $\begin{array}{l}\text { forward, 5'-CTCACCTGCTGCTACTCATTC-3' } \\
\text { reverse, 5'-GCTTGAGGTGGTTGTGGAAAA-3' }\end{array}$ & $317 \mathrm{bp}$ \\
\hline OPG & $\begin{array}{l}\text { forward, 5'-TCCTGGCACCTACCTAAAACAGCA-3' } \\
\text { reverse, 5'-CTACACTCTCGGCATTCACTTTGG-3' }\end{array}$ & $578 \mathrm{bp}$ \\
\hline B-actin & $\begin{array}{l}\text { forward, 5'-CCCACTCCTAAGAGGAGGATG-3' } \\
\text { reverse, 5'-AGGGAGACCAAAGCCTTCAT-3' }\end{array}$ & $214 b p$ \\
\hline
\end{tabular}

Protocol: Intro: $95^{\circ} \mathrm{C}$ in 15 minutes. Denature: $95^{\circ} \mathrm{C}$ in 30 seconds. Anneal: $57^{\circ} \mathrm{C}$ in 30 seconds. Extension: $74^{\circ} \mathrm{C}$ in 60 seconds.

Fluorescence is measured in the Extension-phase.

Real-time PCR was performed with a SYBR-Green real time assay using an ICycler PCR machine (BIO-RAD laboratories Ltd., Hemel Hampstead, UK). Target gene and house-keeping gene (b-actin) were amplified in separate tubes using the following protocol: $95^{\circ} \mathrm{C}$ in 15 minutes, $95^{\circ} \mathrm{C}$ in 30 seconds, $57^{\circ} \mathrm{C}$ in 30 seconds, and $74^{\circ} \mathrm{C}$ in 60 seconds. The fluorescence was measured in real time during 30 seconds at $57^{\circ} \mathrm{C}$, the extension phase. Threshold cycles $\left(\mathrm{C}_{\mathrm{T}}\right)$ were defined as the fractional cycle number at which the fluorescence reached 10 times the standard deviation of the baseline. Relative gene expression of $b$ actin to cytokines was calculated as $1 /\left(2^{\text {(CT Target/CT b-actin })}\right)$, essentially as described in the manufacturer manual (Perkin Elmer Cetus). Samples were amplified in technical duplicates.

\footnotetext{
Assessment of cell viability

Lactate dehydrogenase (LDH) is released from cells when membranes are disrupted. In necrotic cells the membrane is disrupted and LDH escapes the cell. Apoptotic cells will be fragmented into apoptotic bodies which are up taken in macrophages (Fadeel, 2003). LDH was measured using a
}

spectrophotometric evaluation of LDH mediated conversion of pyruvic acid to lactic acid (Department of Clinical Biochemistry, Aarhus University Hospital, Denmark). The LDH content did not vary between the cells incubated 8 hours in the empty polystyrene wells compared to cells incubated with discs (empty wells vs. discs, $\mathrm{p}=0.64$, data not shown).

\section{Discs}

Discs were kindly provided by Biomet ${ }^{\bigcirc}$ USA. Four different types of discs were tested. Wrought $\mathrm{HC}$ CoCrMo; Wrought LC, CoCrMo; as-cast HC CoCrMo; and Wrought TiAlV. Three mm thick discs were machined out of 15 $\mathrm{mm}$ cylinders of the materials. To achieve a physiological endotoxin level (Tatro et al., 2006) discs were cleansed in a single cycle as previously described (Ragab et al., 1999). Endotoxin testing was done by Cambrex testing services (Cambrex Europe, Verviers, Belgium), and to extract endotoxin from the surface of the discs they were first placed on a shaking plate for 10 minutes followed by 30 minutes in an ultrasonic bath. A steady mean $(0.14 \mathrm{EU} / \mathrm{ml}$ \pm 0.04 SEM) was attained. 
Table 2. Mean roughness $\mathrm{R}_{\mathrm{a}}(+/$-SEM) of the different prosthetic materials $(\mathrm{n}=4)$

\begin{tabular}{lcccc}
\hline & $\begin{array}{c}\text { Wrought HC } \\
\text { CoCrMo }\end{array}$ & $\begin{array}{c}\text { Wrought LC } \\
\text { CoCrMo }\end{array}$ & $\begin{array}{c}\text { As-cast HC } \\
\text { CoCrMo }\end{array}$ & Wrought TiAlV \\
\hline Rough surface & $718 \mathrm{~nm}(+/-111 \mathrm{~nm})$ & $546 \mathrm{~nm}(+/-17 \mathrm{~nm})$ & $351 \mathrm{~nm}(+/-11.5 \mathrm{~nm})$ & $340 \mathrm{~nm}(+/-4.2 \mathrm{~nm})$ \\
Polished surface & $6.3 \mathrm{~nm}(+/-1.4 \mathrm{~nm})$ & $7.0 \mathrm{~nm}(+/-2.5 \mathrm{~nm})$ & $12.5 \mathrm{~nm}(+/-1.3 \mathrm{~nm})$ & $21 \mathrm{~nm}(+/-2.0 \mathrm{~nm})$ \\
\hline
\end{tabular}

\section{Surface characterisation}

\section{Surface topography}

The disc surface were characterised with a Dektak 3030 (Veeco/Sloan Technology Division, Santa Barbara, CA, USA) profilometer with a $12.5 \mu \mathrm{m}$ diamond stylus.

To reduce the roughness, discs were mounted with double-faced adhesive tape on a Pedemax-2 test specimen mover plate (Struers, Ballerup, Denmark) and polished with Silicon carbide grinding discs $(\mathrm{SiC})$ on a Planopol-2, Ø $300 \mathrm{~mm}$. (Struers). We started out with a SiC mesh 120 (grain size $125 \mu \mathrm{m}$ ) grinding disc followed by 1200 mesh grinding disc, 2400 mesh grinding disc and finally a 4000 mesh (grain size $5 \mu \mathrm{m}$ ) grinding disc. The double-faced adhesive tape was removed with trichlorethene, acetone, water, and air blown dry.

\section{Surface element composition}

The surface element composition was characterized in a SEM with an EDS (Energy Dispersive System) from EDAX (Mahwah, NJ, USA).

\section{Statistics}

Both cytokine secretion and mRNA transcription data were found not to fit normality of distribution. Concentrations below the detection limit were expressed as one half of the method detection limit. Data were normalised to the mean of the control (control $=1$ ) and non-parametric Kruskall-Wallis ANOVA test with Bonferroni correction for multiple comparison testing was used. A $p<0.05$ was considered significant. Results are given as median with interquartile range (IQR).

\section{Results}

\section{Surface characterisation}

\section{Surface topography}

Initially, roughness varied between $\mathrm{R}_{\mathrm{a}}$ (average roughness), $718 \mathrm{~nm}$ (Wrought HC CoCrMo) to $\mathrm{R}_{\mathrm{a}} 340 \mathrm{~nm}$ (Wrought TiAlV). After polishing, the roughness was greatly reduced and the average varied between $\mathrm{R}_{\mathrm{a}} 6.3 \mathrm{~nm}$ (Wrought LC CoCrMo) and $\mathrm{R}_{\mathrm{a}} 21 \mathrm{~nm}$ (Wrought TiAlV) (Table 2).

\section{Surface element composition}

The surface element composition analysis of CoCrMo discs showed $\mathrm{Co}, \mathrm{Cr}$, and $\mathrm{Mo}$ in the CoCrMo alloys, but in ascast $\mathrm{HC} \mathrm{CoCrMo}$ and wrought $\mathrm{LC}$ CoCrMo we also found traces of $\mathrm{Ni}, \mathrm{Si}, \mathrm{Fe}, \mathrm{Al}$. In TiAlV alloy we found a little more Al than expected, but no trace elements were observed. EDS methodology is not suitable to show differences in carbon content because of the low atomic weight of this element (Table 3).

\section{Time-Course}

Time-course and dose-response studies for main cytokines were done on the mouse J774A.1 macrophages to establish the optimum incubation time for both protein- and transcription level. Lipopolysaccharide (LPS) (SigmaAldrich, Product No. L8274, Brøndby, Denmark) was used to activate the cells. Transcription peaked for all cytokines between 4 and 6 hours. Cytokine early-secretion peaked a little later between 6 and 8 hours, and then dropped rapidly to a near non-stimulated level for a period of 12 hours. Cytokine secretion then demonstrated a late (18-48 hours) increasing tendency (Fig. 1).

Table 3. The element content (Wt \%) of the prosthetic materials, EDS spectrum

\begin{tabular}{lcccc}
\hline Element & $\begin{array}{c}\text { Wrought HC } \\
\text { CoCrMo }\end{array}$ & $\begin{array}{c}\text { Wrought HC } \\
\text { CoCrMo }\end{array}$ & $\begin{array}{c}\text { As-cast HC } \\
\text { CoCrMo }\end{array}$ & Wrought TiAlV \\
\hline $\mathrm{Ti}$ & - & - & - & 88.56 \\
$\mathrm{Co}$ & 63.72 & 64.43 & 63.37 & - \\
$\mathrm{Al}$ & - & - & 0.31 & 7.68 \\
$\mathrm{Cr}$ & 28.79 & 26.75 & 27.78 & - \\
$\mathrm{Mo}$ & 6.61 & 5.86 & 4.69 & - \\
$\mathrm{V}$ & - & - & - & 3.76 \\
$\mathrm{Ni}$ & & 1.83 & 1.12 & - \\
$\mathrm{Si}$ & 0.88 & 0.47 & 0.88 & - \\
$\mathrm{Fe}$ & - & 0.67 & 0.79 & - \\
$\mathrm{C}$ & - & - & 1.06 & - \\
\hline
\end{tabular}


Elisa
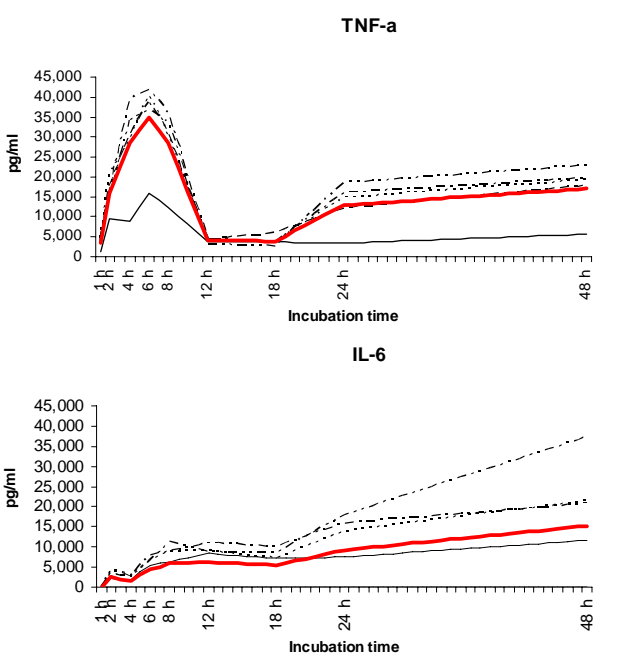

MCP-1

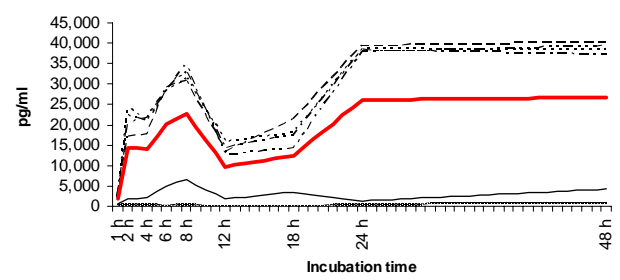

mRNA

$=0 \mathrm{ng} / \mathrm{ml}$

$-10 \mathrm{ng} / \mathrm{ml}$

$-100 \mathrm{ng} / \mathrm{ml}$

. . $500 \mathrm{ng} / \mathrm{ml}$

$-.1000 \mathrm{ng} / \mathrm{ml}$

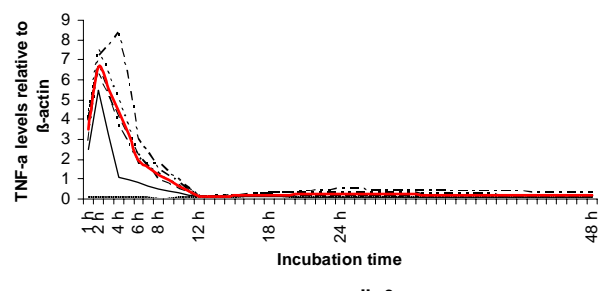

IL-6

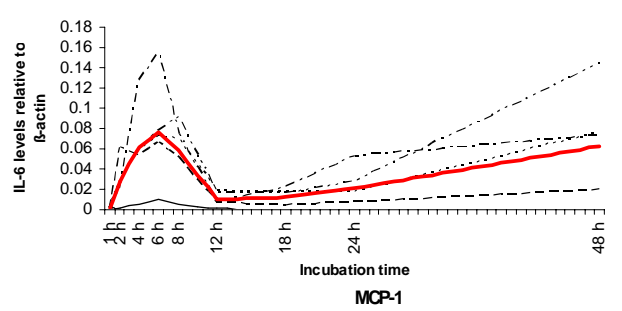

.$-2000 \mathrm{ng} / \mathrm{ml}$

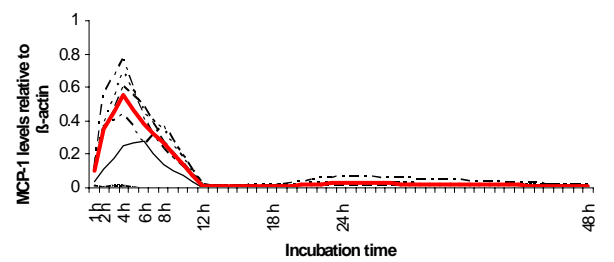

Figure 1. TNF- $\alpha$, IL-6 and MCP-1 protein release and mRNA transcription from time-course and dose response studies. LPS were used as activator.

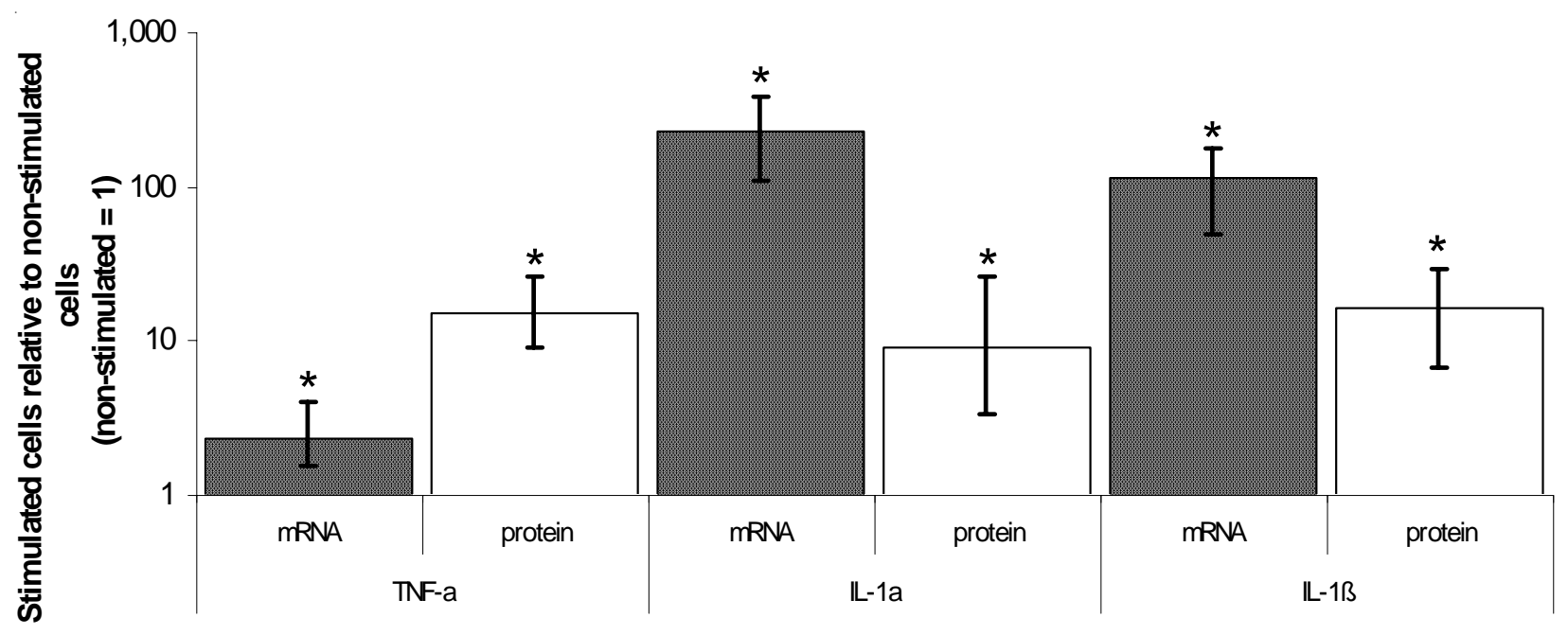

Figure 2. Pooled data between all the different alloys (wrought $\mathrm{HC}$ CoCrMo, wrought LC CoCrMo, as-cast HC CoCrMo and wrought TiAlV). Data are shown relative to non-stimulated cells (Median with IQR; * $: p<0.01$ vs. non-stimulated cells, $\mathrm{n}=40$ ).

\section{Pro-inflammatory response}

\section{TNF- $\alpha$}

TNF- $\alpha$ protein secretion was not affected by the type of prosthetic material. However, when pooling data from all materials a significant 16 -fold increase compared to the secretion from non-stimulated cells was seen $(589 \mathrm{pg} / \mathrm{ml}$ [348-1023] vs. $36 \mathrm{pg} / \mathrm{ml}$ [26-52], $p<0.01)$. mRNA expression showed the same pattern as protein secretion with a 2.4-fold increase of TNF- $\alpha$ mRNA compared to non-stimulated cells $(p<0.01)$ (Fig. 2).

\section{IL-6}

IL-6 protein secretion was not affected by type of prosthetic material but when the data from the stimulated cells were pooled a significant 295 -fold increase was seen compared to non-stimulated cell secretion $(1.3 \mathrm{pg} / \mathrm{ml}$ [1.0-1.5] vs. $384 \mathrm{pg} / \mathrm{ml}$ [180/631], $p<0.01)$. Cells incubated with as- 


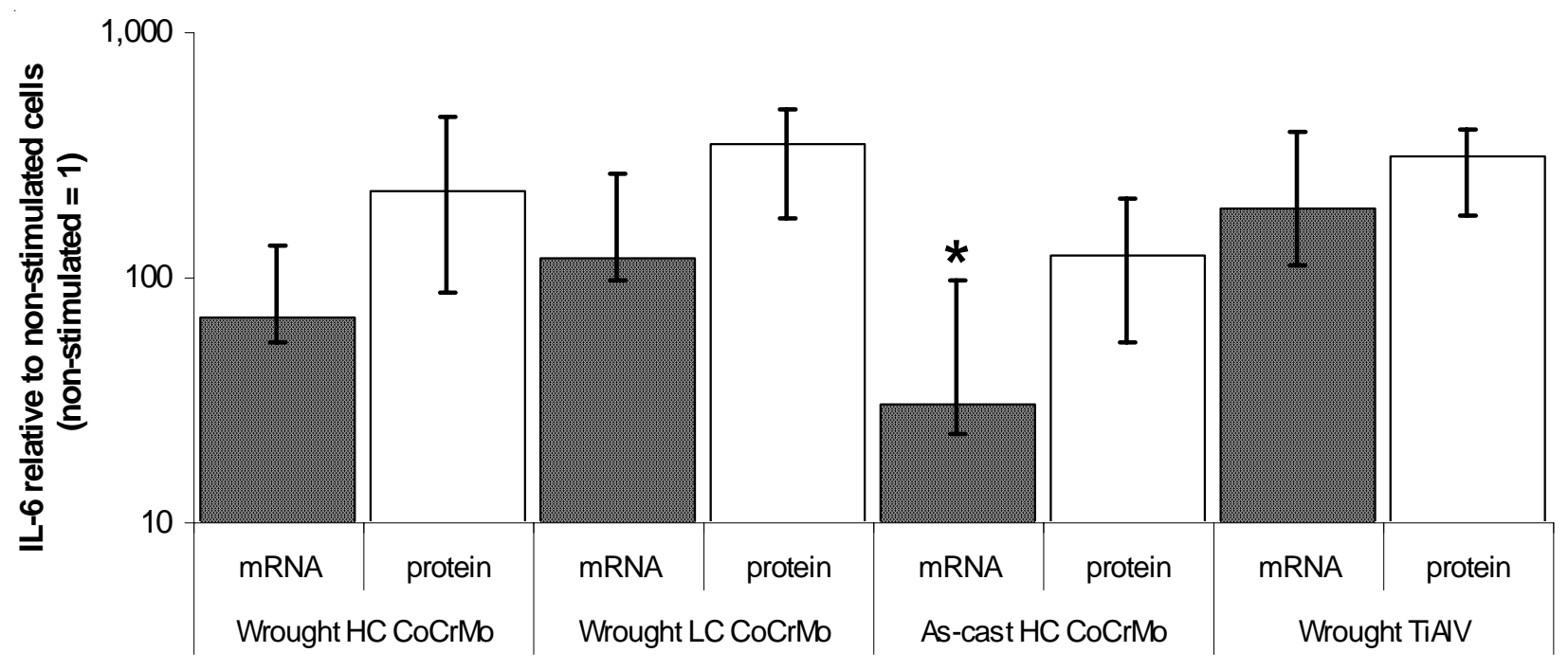

Figure 3. IL-6 protein secretion and mRNA transcription from J774A.1 macrophages incubated with the different prosthetic alloys relative to non-stimulated cells (Median with IQR; * : $p<0.029$ vs. wrought TiAlV, $\mathrm{n}=10$ ).

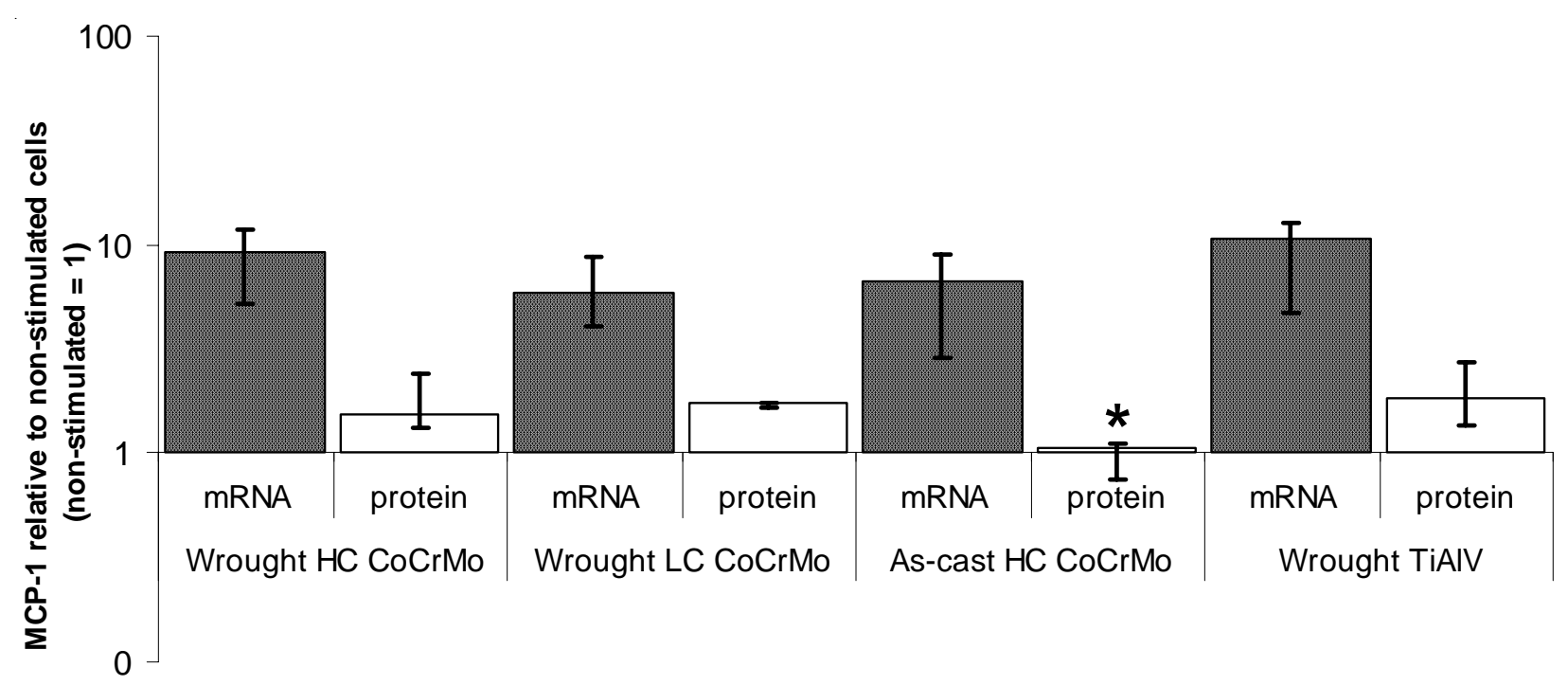

Figure 4. MCP-1 protein secretion and mRNA transcription from J774A.1 cells incubated with the different prosthetic alloys relative to non-stimulated cells (Median with IQR; * : $p<0.05$ vs. Wrought HC CoCrMo, Wrought LC CoCrMo, and wrought TiAlV, $\mathrm{n}=10$ ).

cast $\mathrm{HC}$ CoCrMo showed a significant $(p=0.029)$ suppression of IL-6 mRNA compared to TiAlV (Fig. 3). The reduction observed for as-cast HC CoCrMo was 77\% compared to the rest of the materials. Pooled data for all other materials exhibited a 130 -fold increase in mRNA compared to non-stimulated cells $(p<0.01)$.

\section{IL-1 $\alpha$}

IL- $1 \alpha$ protein secretion was not affected by type of prosthetic material, but when the data from the stimulated cells were pooled a significant 11 -fold increase was seen compared to non-stimulated cell secretion $(3 \mathrm{pg} / \mathrm{ml}[2.1$ 4.7] vs. $32 \mathrm{pg} / \mathrm{ml}$ [12-85], $p<0.01)$. mRNA increase was 229 -fold compared to non-stimulated cells $(p<0.01)$ (Fig. 2).

\section{IL-1 $\beta$}

IL1 $\beta$ protein secretion was not affected by type of prosthetic material, but when the data from the stimulated cells were pooled a significant 11-fold increase was seen compared to non-stimulated cell secretion $(4.7 \mathrm{pg} / \mathrm{ml}[0$ $10.8]$ vs. $94 \mathrm{pg} / \mathrm{ml}[41 / 191], p<0.01)$. mRNA increase was 115 -fold compared to non-stimulated cells $(p<0.01)$ (Fig. 2).

\section{Chemokine response}

\section{MCP-1}

MCP-1 protein secretion was significantly reduced by $36 \%$ when cells were incubated with as-cast $\mathrm{HC}$ CoCrMo compared to secretion from wrought $\mathrm{HC}$ CoCrMo, wrought LC CoCrMo, and TiAlV (5.2 pg/ml [4.1-6.6] vs. $3.3 \mathrm{pg} / \mathrm{ml}[2.5 / 3.4], p<0.05)$. Pooling data from all materials showed a 7.3 -fold mRNA increase compared to nonstimulated cells $(p<0.01)$, but was not suppressed by ascast HC CoCrMo (Fig. 4). 


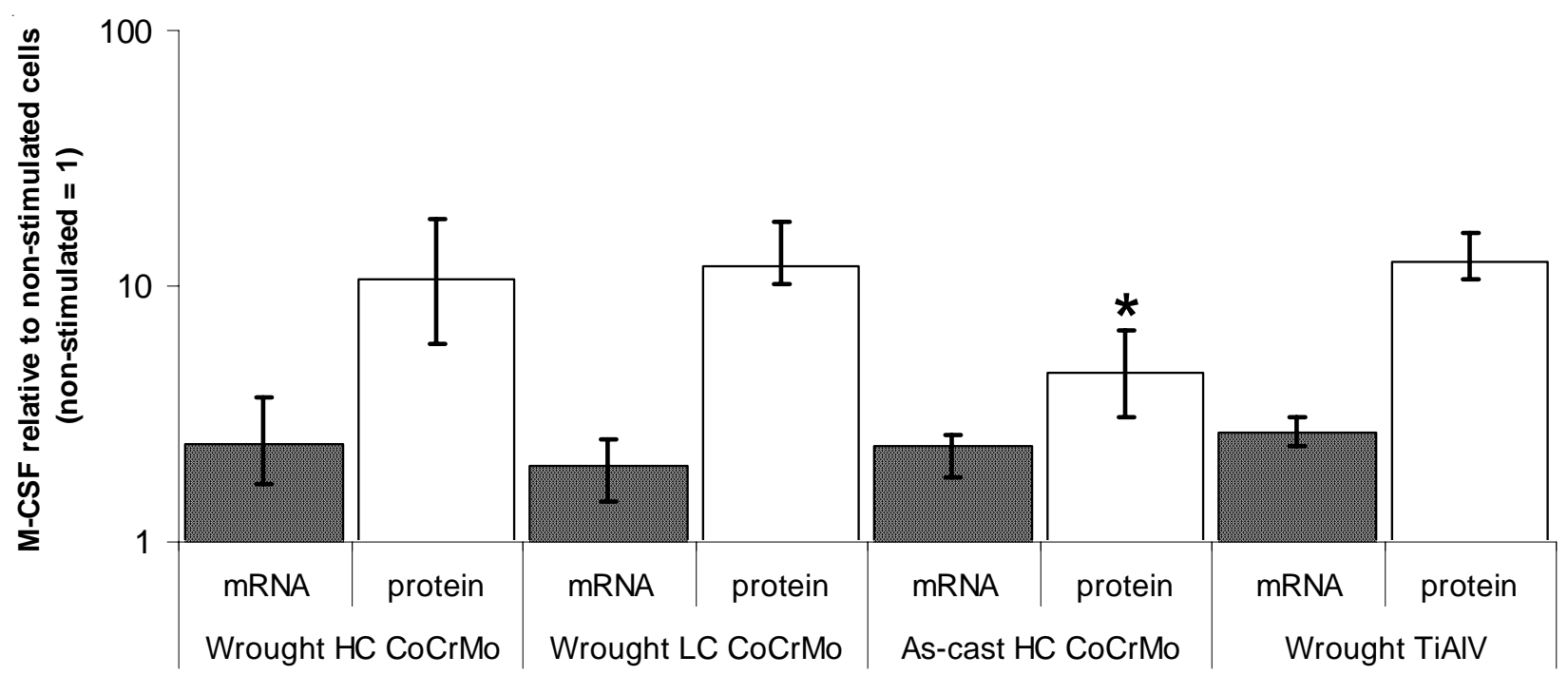

Figure 5. M-CSF protein secretion and mRNA transcription from J774A. 1 cells incubated with the different prosthetic alloys relative to non-stimulated cells (Median with IQR; * $: p<0.01$ vs. Wrought HC CoCrMo, Wrought LC CoCrMo and wrought TiAlV, $\mathrm{n}=10$ ).

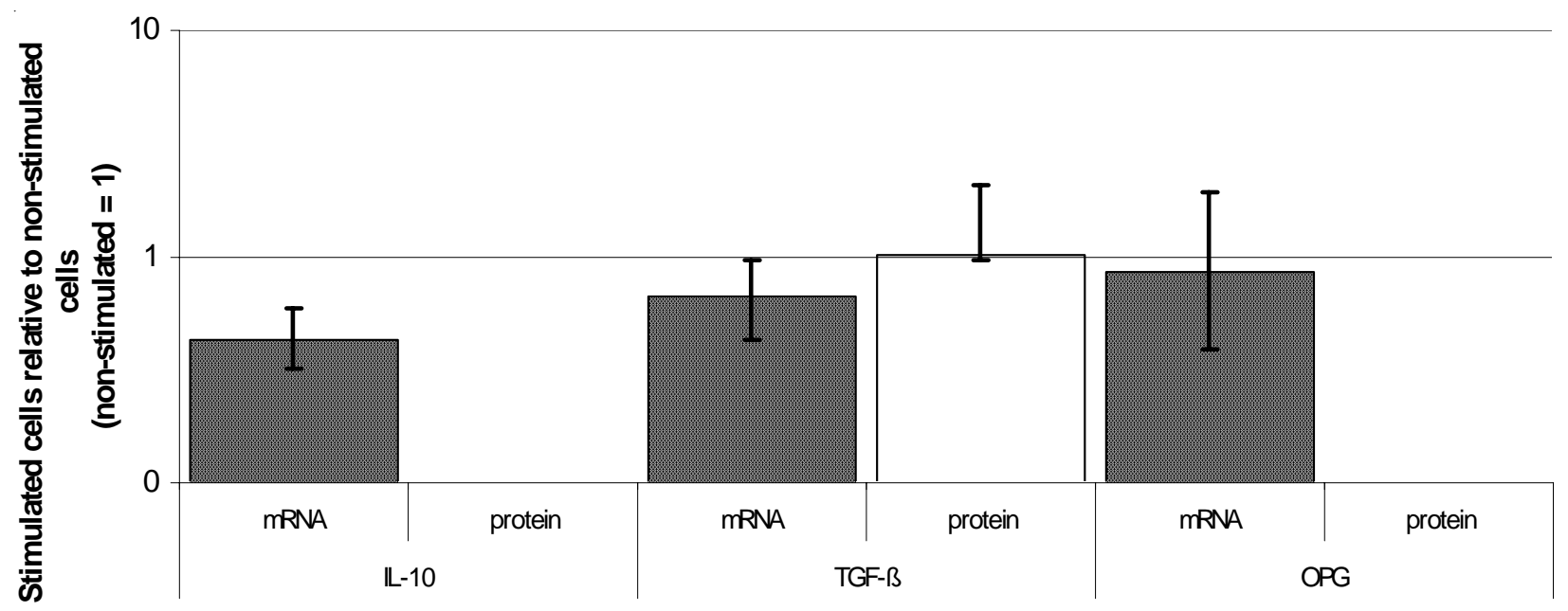

Figure 6. Pooled IL-10, TGF- $\beta$, and OPG protein secretion and mRNA transcription from J774A.1 cells incubated with wrought $\mathrm{HC}$ CoCrMo, wrought LC CoCrMo, as-cast HC CoCrMo, and wrought TiAlV discs relative to nonstimulated cells. No detectable levels of IL-10 and OPG protein were secreted (Median with IQR; ${ }^{*}: p<0.05$ vs. nonstimulated cells, TGF- $\beta$ : $n=40$, OPG and IL-10: $n=10$ ).

\section{Profilerative response}

\section{M-CSF}

M-CSF protein secretion was significantly reduced by $62 \%$ when cells were incubated with as-cast $\mathrm{HC} \mathrm{CoCrMo}$ compared to secretion from wrought $\mathrm{HC} \mathrm{CoCrMo}$, wrought LC CoCrMo, and TiAlV (39 pg/ml [25-53] vs. $15 \mathrm{pg} / \mathrm{ml}[9.8-21], p<0.01)$. Pooled data from wrought $\mathrm{HC}$ CoCrMo, wrought LC CoCrMo, and TiAlV were 13-fold increased compared to non-stimulated cells (39 pg/ml [2553] vs. $1.9 \mathrm{pg} / \mathrm{ml}$ [0-6.1], $p<0.01)$. Pooled mRNA data from all different alloys exhibited a 2.6-fold increase compared to non-stimulated cells $(p<0.01)$ but was not suppressed by as-cast HC CoCrMo (Fig. 5).

\section{Anti-inflammatory response}

\section{IL-10}

The protein secretion of IL-10 was undetectable. mRNA was not affected by any of the prosthetic materials. IL-10 mRNA was modestly reduced by 0.43 -fold compared to non-stimulated cells, but this did not reach statistical significance (Fig. 6).

\section{Bone-generating response}

\section{OPG}

The protein secretion of OPG was undetectable. mRNA was not affected by any of the prosthetic materials. OPG mRNA was modestly reduced by 0.85 -fold compared to non-stimulated cells, but this did not reach statistical significance (Fig. 6). 


\section{TGF- $\beta$}

Macrophages transcripted and secreted steady levels of TGF- $\beta$ and this was not affected by implant material; stimulated cell protein secretion was almost equal to nonstimulated cell levels (710 pg/ml [673-749] vs. $700 \mathrm{pg} / \mathrm{ml}$ [664-775], $p>0.05)$. TGF- $\beta$ mRNA was modestly reduced by to $70 \%$ of the level in non-stimulated cells, but this did not reach statistical significance (Fig. 6).

\section{Discussion}

CoCrMo alloys have had a revival in metal-on-metal prosthetic designs as an alternative to the prosthetic designs using polyethylene. The success of CoCrMo alloys depends on the biocompatible properties. We here report, that the implant surface (non-phagocytable) of as-cast HC CoCrMo reduce the mouse J774A.1 IL-6 transcription, MCP-1 protein secretion, and M-CSF protein secretion by $77 \%, 36 \%$, and $62 \%$, respectively.

We used the mouse cell line J774.A1 because of the close resemblance to macrophages seen in the proximity of prosthesis and cement in humans (Bockman, 1981; Catelas et al., 1999; Horowitz et al., 1993). Non-stimulated J774A. 1 cells tend to be less activated and thereby create a more uniform inflammatory response, when delicate changes are studied, than isolated human monocytes/ macrophages.

LPS time-course and dose-response studies were performed to follow the course of both mRNA and protein production (Fig. 1). The results indicate that for TNF- $\alpha$, IL-6, and MCP-1 8 hours was ideal. Ideally time-course experiments should be done with metal discs; however, the response generated is so small that this would be very impractical. Time-course experiments indicate that optimum incubation time for mRNA assays would be 4-6 hours; however, time-course experiments were done on LPS activated macrophages which undoubtedly generates an earlier response compared to metal-surfaces. The protein secretion for the examined cytokines peaks 2-3 hours later than the mRNA expression, leaving 8 hours incubation time optimal for both protein secretion and mRNA transcription.

We investigated cytokines important for bone degradation that have been observed in tissue from clinical cases of aseptic loosening (pro-inflammatory, chemotaxis, and proliferation) (Goodman 2005; Wooley and Schwarz 2004) and we also investigated an anti-inflammatory and bone generating response. All cytokines were known to be secreted by human macrophages.

IL-6, MCP-1, and M-CSF are important proteins for the regulation of bone resorption. Osteoclasts are the final common pathway in osteoloysis, and the bone resorption is dependent on the number of osteoclasts, activity, and survival of osteoclasts. An increase in number of osteoclasts is observed, when monocytes are exposed to M-CSF via the c-fms receptor (Sabokbar et al., 2003; Tanaka et al., 1993). MCP-1 increases bone resorption by attracting monocytes and activating already present osteoclasts (Gillitzer and Goebeler, 2001). Finally, IL-6 induces osteoclast formation and is involved in both bone resorption and bone formation in the remodelling stage (Jilka et al., 1992; Takeuchi et al., 2001). It has been proposed that TiAlV induces higher IL- 6 secretion as compared to CoCrMo, whereas CoCrMo alloys induce higher TNF- $\alpha$ secretion (Wooley and Schwarz, 2004). This distinction has previously been reported in RAW 264.7 cells (Sethi et al., 2003). In line with these findings, we found TiAlV to reduce TNF- $\alpha$ secretion by $\sim 50 \%$ compared to CoCrMo alloys and TiAlV to increase IL-6 secretion by $\sim 100 \%$ as compared to as-cast HC CoCrMo. As opposed to Sethi et al. (2002), using both wrought and as-cast $\mathrm{CoCrMo}$, we observed that only as-cast CoCrMo suppressed IL-6 compared to TiAlV, but the increase in TNF- $\alpha$ was seen for both wrought and as-cast CoCrMo alloys. TNF- $\alpha$ increases osteoclast survival rate (Lee et al., 2001), transforms osteoclast precursors to mature osteoclasts (Lam et al., 2000), and activates resident nonactivated osteoclasts even at very low levels (e.g. 100 pg/ $\mathrm{ml}$ ) (Fuller et al., 2002). Il-1 $\alpha$ and $\beta$ is found in abundance in periprosthetic tissue from loose implants. Together with TNF- $\alpha$ they stimulate osteoblasts to express RANKL and M-CSF, thereby stimulating osteoclasts (Hofbauer et al., 1999; Mundy, 1993).

Wear particles are strongly correlated to aseptic loosening but in line with Sethi et al. (Sethi et al., 2003) we observed a large statistically significant increase in TNF- $\alpha$, IL-6, IL- $1 \alpha$ and $\beta$ transcription and secretion from cells incubated with discs (pooled data from all the different alloys) (Figs.1 and 3) compared to non-stimulated cells. These findings can be explained by the fact that macrophages express and secrete cytokines independently of the internalization process (Bi et al., 2002; Fritz et al., 2006; Nakashima et al., 1999). In physiological environment adherent endotoxin is unavoidable (Tatro et al., 2006) and may also contribute to the pro-inflammatory response generated by the foreign objects in the body. Endotoxin is ubiquitous remnants from gram-negative cell walls, with a strong pro-inflammatory capacity. Particles with adherent endotoxin generates a larger proinflammatory response in cell cultures than particles without endotoxin (Bi et al, 2002; Cho et al., 2002).

Bone generating cytokines are obviously very important, when prosthetic devices are implanted. In our study, transcription was reduced by IL-10 (54\%), OPG $(15 \%)$, and TGF- $\beta$ (30\%) for pooled data of all discs compared to non-stimulated cells. However, none of the reductions were statistically significant. Secretion of IL10 is stimulated by pro-inflammatory cytokines and exhibit anti-inflammatory effects through a down-regulation of pro-inflammatory signals (IL- $1 \alpha$ and $\beta$, TNF- $\alpha$, M-CSF, IL-6, $\mathrm{O}_{2}^{-}$and $\mathrm{NO}$ ) and antigen presenting receptor MHCII. TGF- $\beta$ is of importance in osseous wound healing, probably through a stimulation of collagen synthesis combined with an inhibition of collagen degradation and transformation of progenitor cells to active osteoclasts (Bostrom and Asnis, 1998; Heine et al., 1987). OPG decreases osteoclast activity by blocking the RANKL sites on stromal cells (Udagawa, 2002).

Prosthetic surface structure (porosity, surface roughness) influences osteointegration and prosthetic fixation greatly (Bobyn et al., 1980). Surfaces also 
influence immunoactive cells as macrophages. We did not find any differences in the pro-inflammatory response between polished or rough discs; both rough and as-cast discs were able to suppress IL-6, MCP-1, and M-CSF. Macrophages cultured on a rough surface together with mouse calvariae show increasing ${ }^{45} \mathrm{Ca}$ immersion compared to macrophages cultured on a smooth surface (Murray et al., 1989). The specific relationship between surface topography, inflammations and tissue regeneration has not yet been established, but it has been suggested that roughened surfaces influence macrophage adhesion, proliferation and activation (Thomsen and Gretzer 2001). Between CoCrMo alloys the atomic composition is very similar (Table 3). When an attempt is made to explain the observed suppression, the possibility of an unknown third factor in the macrophage - surface interaction must be considered. In the initial phase of implantation it is not obvious that early suppressing effects on M-CSF, IL-6, and MCP-1 are advantageous. In the reparative phase, chemokines, pro-inflammatory and proliferate cytokines are important mediators in normal wound healing in bone. Another picture could be seen in the long run, where a chronic foreign body reaction could be avoided by a very low stimulating effect of the implant material.

Three mechanisms should be considered when trying to avoid osteolysis (Wang et al., 2004). First, on which we hereby concentrate, exacerbated inflammation by activated macrophages; second, impaired periprosthetic bone development secondary to disrupted osteogenesis; and third, compromised bone regeneration resulting from increased cytotoxicity of mesenchymal stem cells. Future co-culture and in vivo studies should be aimed at evaluating CoCrMo in respect to these mechanisms to provide at full description of the expected role CoCrMo in aseptic loosening.

\section{Acknowledgements}

The authors received generous support from The Danish Rheumatism Association, and Aarhus Universitetshospitals Forskningsinitiativ. We are grateful to Mrs. Janne Svejstrup (Institute of Anatomy), Mrs. Lene Munkøe (Institute of Anatomy), Ms. Pia Hornbek, and Ms. Lenette Pedersen for their skilful technical assistance. Biomet Inc., Warsaw, IN, USA kindly donated the discs. We are greatly indebted to Professor dr. med. Gorm Danscher for enthusiastic discussions and his valuable advice.

\section{References}

Bi Y, Collier TO, Goldberg VM, Anderson JM, Greenfield EM (2002) Adherent endotoxin mediates biological responses of titanium particles without stimulating their phagocytosis. J Orthop Res 20: 696-703.

Bobyn JD, Pilliar RM, Cameron HU, Weatherly GC, Kent GM (1980) The effect of porous surface configuration on the tensile strength of fixation of implants by bone ingrowth. Clin Orthop Relat Res 149: 291-298.
Bockman RS (1981) Prostaglandin production by human blood monocytes and mouse peritoneal macrophages: synthesis dependent on in vitro culture conditions. Prostaglandins 21: 9-31.

Bostrom MP, Asnis P (1998) Transforming growth factor beta in fracture repair. Clin Orthop Relat Res 355 : S124-S131.

Catelas I, Petit A, Marchand R, Zukor DJ, Yahia L, Huk OL (1999) Cytotoxicity and macrophage cytokine release induced by ceramic and polyethylene particles in vitro. J Bone Joint Surg Br 81: 516-521.

Catelas I, Petit A, Zukor DJ, Antoniou J, Huk OL (2003) TNF-alpha secretion and macrophage mortality induced by cobalt and chromium ions in vitro-qualitative analysis of apoptosis. Biomaterials 24: 383-391.

Cho DR, Shanbhag AS, Hong CY, Baran GR, Goldring SR (2002) The role of adsorbed endotoxin in particleinduced stimulation of cytokine release. J Orthop Res 20: 704-713.

Danscher G (2002) In vivo liberation of gold ions from gold implants. Autometallographic tracing of gold in cells adjacent to metallic gold. Histochem Cell Biol 117: 447452.

Fadeel B (2003) Programmed cell clearance. Cell Mol Life Sci 60: 2575-2585.

Firkins PJ, Tipper JL, Saadatzadeh MR, Ingham E, Stone MH, Farrar R, Fisher J (2001) Quantitative analysis of wear and wear debris from metal-on-metal hip prostheses tested in a physiological hip joint simulator. Biomed Mater Eng 11: 143-157.

Fritz EA, Glant TT, Vermes C, Jacobs JJ, Roebuck KA (2006) Chemokine gene activation in human bone marrowderived osteoblasts following exposure to particulate wear debris. J Biomed Mater Res A 77: 192-201

Fuller K, Murphy C, Kirstein B, Fox SW, Chambers TJ (2002) TNFalpha potently activates osteoclasts, through a direct action independent of and strongly synergistic with RANKL. Endocrinology 143: 1108-1118.

Futami T, Fujii N, Ohnishi H, Taguchi N, Kusakari H, Ohshima H, Maeda T (2000) Tissue response to titanium implants in the rat maxilla: ultrastructural and histochemical observations of the bone-titanium interface. J Periodontol 71: 287-298.

Garrigues GE, Cho DR, Rubash HE, Goldring SR, Herndon JH, Shanbhag AS (2005) Gene expression clustering using self-organizing maps: analysis of the macrophage response to particulate biomaterials. Biomaterials 26: 2933-2945.

Gillitzer R, Goebeler M (2001) Chemokines in cutaneous wound healing. J Leukoc Biol 69: 513-521.

Goodman S (2005) Wear particulate and osteolysis. Orthop Clin North Am 36: 41-48.

Heine U, Munoz EF, Flanders KC, Ellingsworth LR, Lam HY, Thompson NL, Roberts AB, Sporn MB (1987) Role of transforming growth factor-beta in the development of the mouse embryo. J Cell Biol 105: 28612876.

Hofbauer LC, Lacey DL, Dunstan CR, Spelsberg TC, Riggs BL, Khosla S (1999) Interleukin-1beta and tumor necrosis factor-alpha, but not interleukin-6, stimulate 
osteoprotegerin ligand gene expression in human osteoblastic cells. Bone 25: 255-259.

Horowitz SM, Doty SB, Lane JM, Burstein AH (1993) Studies of the mechanism by which the mechanical failure of polymethylmethacrylate leads to bone resorption. J Bone Joint Surg Am 75: 802-813.

Horowitz SM, Luchetti WT, Gonzales JB, Ritchie CK (1998) The effects of cobalt chromium upon macrophages. J Biomed Mater Res 41: 468-473.

Ingham E, Fisher J (2005) The role of macrophages in osteolysis of total joint replacement. Biomaterials 26: 1271 1286.

Jilka RL, Hangoc G, Girasole G, Passeri G, Williams DC, Abrams JS, Boyce B, Broxmeyer H, Manolagas SC (1992) Increased osteoclast development after estrogen loss: mediation by interleukin-6. Science 257: 88-91.

Kao WJ, Hubbell JA, Anderson JM (1999) Proteinmediated macrophage adhesion and activation on biomaterials: a model for modulating cell behavior. J Mater Sci Mater Med 10: 601-605.

Lam J, Takeshita S, Barker JE, Kanagawa O, Ross FP, Teitelbaum SL (2000) TNF-alpha induces osteoclastogenesis by direct stimulation of macrophages exposed to permissive levels of RANK ligand. J Clin Invest 106: 1481-1488.

Larsen A, Stoltenberg M, Danscher G (2007) In vitro liberation of charged gold atoms: autometallographic tracing of gold ions released by macrophages grown on metallic gold surfaces. Histochem Cell Biol, 128: 1-6.

Lee SE, Chung WJ, Kwak HB, Chung CH, Kwack KB, Lee ZH, Kim HH (2001) Tumor necrosis factor-alpha supports the survival of osteoclasts through the activation of Akt and ERK. J Biol Chem 276: 49343-49349.

Lee SH, Brennan FR, Jacobs JJ, Urban RM, Ragasa DR, Glant TT (1997) Human monocyte/macrophage response to cobalt-chromium corrosion products and titanium particles in patients with total joint replacements. J Orthop Res 15: 40-49.

Mundy GR (1993) Role of cytokines in bone resorption. J Cell Biochem 53: 296-300.

Murray DW, Rae T, Rushton N (1989) The influence of the surface energy and roughness of implants on bone resorption. J Bone Joint Surg Br 71: 632-637.

Nakashima Y, Sun DH, Trindade MC, Maloney WJ, Goodman SB, Schurman DJ, Smith RL (1999) Signaling pathways for tumor necrosis factor-alpha and interleukin6 expression in human macrophages exposed to titaniumalloy particulate debris in vitro. J Bone Joint Surg Am 81: 603-615.

Nevelos.J, Shelton.J.C., Fisher.J (2004) Metallurgical considerations in the wear of metal-on-metal bearings. HIP Int 14: 1-10.

Ragab AA, Van De MR, Lavish SA, Goldberg VM, Ninomiya JT, Carlin CR, Greenfield EM (1999) Measurement and removal of adherent endotoxin from titanium particles and implant surfaces. J Orthop Res 17: 803-809.

Roach P, Eglin D, Rohde K, Perry CC (2007) Modern biomaterials: a review-bulk properties and implications of surface modifications. J Mater Sci Mater Med 18: 1263 1277.
Sabokbar A, Kudo O, Athanasou NA (2003) Two distinct cellular mechanisms of osteoclast formation and bone resorption in periprosthetic osteolysis. J Orthop Res 21: $73-80$.

Sennerby L, Thomsen P, Ericson LE (1993) Early tissue response to titanium implants inserted in rabbit cortical bone. Journal of Materials Science: Materials in Medicine 4: 494-502.

Sethi RK, Neavyn MJ, Rubash HE, Shanbhag AS (2003) Macrophage response to cross-linked and conventional UHMWPE. Biomaterials 24: 2561-2573.

Takeuchi T, Tsuboi T, Arai M, Togari A (2001) Adrenergic stimulation of osteoclastogenesis mediated by expression of osteoclast differentiation factor in MC3T3E1 osteoblast-like cells. Biochem Pharmacol 61: 579-586.

Tanaka S, Takahashi N, Udagawa N, Tamura T, Akatsu T, Stanley ER, Kurokawa T, Suda T (1993) Macrophage colony-stimulating factor is indispensable for both proliferation and differentiation of osteoclast progenitors. J Clin Invest 91: 257-263.

Tatro JM, Taki N, Islam AS, Goldberg VM, Rimnac CM, Doerschuk CM, Stewart MC, Greenfield EM (2006) The balance between endotoxin accumulation and clearance during particle-induced osteolysis in murine calvaria. J Orthop Res 25: 261-369.

Thomsen P, Gretzer C (2001) Macrophage interactions with modified material surfaces. Current Opinion in Solid State and Materials Science 5: 163-176.

Udagawa N (2002) Mechanisms involved in bone resorption. Biogerontology 3: 79-83.

Walivaara B, Aronsson BO, Rodahl M, Lausmaa J, Tengvall P (1994) Titanium with different oxides: in vitro studies of protein adsorption and contact activation. Biomaterials 15: 827-834.

Wang ML, Sharkey PF, Tuan RS (2004) Particle bioreactivity and wear-mediated osteolysis. J Arthroplasty 19: $1028-1038$.

Wooley PH, Schwarz EM (2004) Aseptic loosening. Gene Ther 11: 402-407.

Zdolsek JM, Olsson GM, Brunk UT (1990) Photooxidative damage to lysosomes of cultured macrophages by acridine orange. Photochem Photobiol 51: 67-76.

Ziats NP, Miller KM, Anderson JM (1988) In vitro and in vivo interactions of cells with biomaterials. Biomaterials 9: 5-13.

\section{Discussion with Reviewers}

J. Hunt: There is a significant gap between what was done experimentally in cell culture and its clinical relevance for these materials and the cell type used in culture. The authors should comment on the extent to which these experiments are applicable and indicative to the human application. Authors: Previously, in traditional THA CoCrMo was mainly used for femur heads. However, the increasing use of resurfacing implants and un-cemented femur stems (Morshed et al., 2007) have introduced a potential problem with bulk CoCrMo since CoCrMo implant surfaces may now be involved in the complex cellular and molecular 
response in osseous wound healing. The authors have considered bone healing in relation to implantation like a series of events, where the final result and success is dependent each of these events. In osseous wound healing several cell-types including osteoblasts, osteoclast, and macrophages all play a pivotal role with the ability to affect the above mentioned series of events in a deleterious way, essentially making an implant fail (inferior results). Especially macrophages seem to be essential in the current understanding of aseptic loosening (Ingham and Fisher, 2005; text reference). Since only few studies have investigated the surface (non-phagocytable foreign body) of implants where macrophages interact with both corrosive products and surface properties the present study was performed.

J.Hunt: The relevance of J744 cells for the implied significance of the findings in this study is questioned. This study lacks evidence or proof that the J744 cells in this study are comparable to human macrophages or that they are comparable to Catelas et al. (1999; text reference). The results from these cells cannot be relied upon or extrapolated without characterisation that they are indicative of previous findings of other groups or translatable to a completely different species that being the human cell type in this case. These cells could be used to provide a relative indication of the differences between the materials in this study alone. Please comment.

Authors: The authors agree that one has to be careful before extrapolating these results into a human clinical setting. We used the murine J774A. 1 cell line because it is reported to create a more uniform inflammatory response when studying delicate changes, than harvested isolated human monocytes/macrophages (Horowitz et al., 1993;Sethi et al., 2003; text references). The J774A.1 cell line have demonstrated several effects [patterns] comparable to that of human macrophages, e.g. phagocytosis, transcription and release of proinflammatory cytokines when activated, transcription and release of TGF- $\beta$, transcription of BMP-2 at rest (nonactivated), and finally the ability to speed out on a surface [Bockman, 1981; Catelas et al., 1999; Horowitz et al., 1993 (all text references); Takebe et al., 2007]. In agreement with these reports, we have in the present study and other current studies observed the same basic features in our J774A. 1 cell line - e.g. the ability to perform phagocytosis of specific particles (CoCrMo, Gold, Platinum, polyethylene), to release and/or transcript a wide variety of cytokines (e.g., TNF- $\alpha$, IL-1 $\alpha$, IL-1 $\beta$, IL-4, IL-6, MCP1 , M-CSF, OPG, TGF- $\beta$, IL-10) in response to various stimuli [e.g. CoCrMo discs, Titanium discs, and Ultra High Molecular Polyethylene discs as well as commercial 3Dsurfaces, and Lipopolysacharide], and to spread out on a surface (gold). The authors agree that studies performed in cell lines/cultures often provide early pieces of information only, which has to be further investigated in more advanced models in order to be able to extrapolate into a human context. Cell lines, however, still provides valuable information when trying to control the number of variables in biomedical research.

\section{Additional References}

Morshed S, Bozic KJ, Ries MD, Malchau H, Colford JM, Jr. (2007) Comparison of cemented and uncemented fixation in total hip replacement. Acta Orthop 78: 315326.

Takebe J, Ito S, Champagne CM, Cooper LF, Ishibashi K (2007) Anodic oxidation and hydrothermal treatment of commercially pure titanium surfaces increases expression of bone morphogenetic protein-2 in the adherent macrophage cell line J774A.1. J Biomed Mater Res A 80: 711-718. 